\title{
Final Report: Analysis of Tank 41H Saltcake Sample \# 2 and Comparison to Sample \#1
}

by

D. T. Hobbs

Westinghouse Savannah River Company

Savannah River Site

Aiken, South Carolina 29808

C. J. Coleman

This paper was prepared in connection with work done under the above contract number with the U.S.

Department of Energy. By acceptance of this paper, the publisher and/or recipient acknowledges the U.S. Government's right to retain a nonexclusive, royalty-free license in and to any copyright covering this paper, along with the right to reproduce and to authorize others to reproduce all or part of the copyrighted paper. 


\section{DISCLAIMER}

This report was prepared as an account of work sponsored by an agency of the United States Government. Neither the United States Government nor any agency thereof, nor any of their employees, makes any warranty, express or implied, or assumes any legal liability or responsibility for the accuracy, completeness, or usefulness of any information, apparatus, product, or process disclosed, or represents that its use would not infringe privately owned rights. Reference herein to any specific commercial product, process, or service by trade name, trademark, manufacturer, or otherwise does not necessarily constitute or imply its endorsement, recommendation, or favoring by the United States Government or any agency thereof. The views and opinions of authors expressed herein do not necessarily state or reflect those of the United States Government or any agency thereof.

This report has been reproduced directly from the best available copy.

Available to DOE and DOE contractors from the Office of Scientific and Technical Information, P. O. Box 62, Oak Ridge, TN 37831; prices available from (423) 576-8401.

Available to the public from the National Technical Information Service, U. S. Department of Commerce, 5285 Port Royal Road, Springfield, VA 22161. 


\section{DISCLAIMER}

Portions of this document may be illegible electronic image products. Images are produced from the best available original document. 
WESTINGHOUSE SAVANNAH RIVER COMPANY SAVANNAF RTVER TECHNOLOGY CENTER

To:

S. D. Fink, 773-A<smiles>CCC(C)CC1CCCCC1</smiles>

C.9. Bleven

From: D. T. Hobbs, 773-A and C. J. Coleman, 773-A

Technical Reviewer:

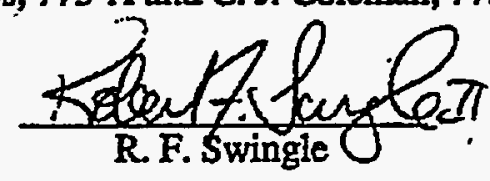

WSRC-TR-94-05T

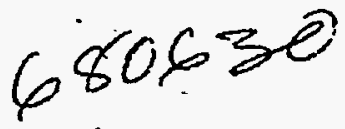

0057

Keywords: High-level waste, Criticality, ITP, Salt, Putonium, Uranium, Isotopics, Chemical, Elemental, Radiochemical

January 26, 1994

Final Report: Analysis of Tank 41 H Saltcake Sample \#2 and Comparison to Sample \#1(U)

\section{SUMMARY}

Three saltcake samples taken from Tank 41H on July 12-13, 1993 have been analyzed for chemical and radiochemical content, identification of crystalline phases, and solubility in inhibited water and compared to the results for the earlier sample taken in March 1993. The maximum total uranium content of the as-received samples was determined to range from 3.0 to $7.3 \mu \mathrm{g} / \mathrm{g}$ with a maximum uranium-235 enrichment of between 15 and $16 \%$ at the $95.2 \%(2 \sigma)$ confidence level. The maximum total plutonium content was determined to range from 0.034 to $0.061 \mu \mathrm{g} / \mathrm{g}$ with a maximum Pu-239 enrichment of between 26 and $32 \%$ at the $95.2 \%(2 \sigma)^{\prime}$ confidence level.

Based on the ICP/MS data, uranium appears to be distributed uniformily radially, but not vertically in the top 12-inch layer of the saltcake. There was approximately a factor of two difference in the uranium content betwcen the top sample $(6.0 \mu \mathrm{g} / \mathrm{g})$ and the bottom sample $(2.7 \mu \mathrm{g} / \mathrm{g})$. All of the samples were comprised of a mixture of light and dark solids. The lightcolored solids readily dissolved in inhibited water. Uranium and plutonium were not uniformly distributed among the white and dark solids. Less than 5\% of the total plutonium, but 63-82\% of the total uranium was determined to be associated with the water-soluble solids fraction of the samples.

Based on the chemical and radiochemical analytical results, the salt solution that will be produced upon dissolution of the saltcake would have the following impacts on ITP processing: (1) the salt solution in Tank $48 \mathrm{H}$ will exceed the current process requirement for insoluble solids content of $400 \mathrm{mg} / \mathrm{L}_{3}$ (2) the removal of Sr-90 would not be necessary to meet the recommended Saltstone feed requirements, and (3) the amount of potassium tetraphenylborate precipitate that will be produced in the ITP process will be $10-25 \%$ of that based on the average flowsheet. 
WSRC-TR-94-057

- page 2 -

January 26, 1994

\section{INTRODUCTION}

Several nuclear safety issues have arisen associated with the dissolution of salt presently stored in Tank $41 \mathrm{H}$. Based on estimates of the inventory of plutonium and uranium in the tank, the accumulation of a critical mass of uranium and, to a lesser extent, of plutonium is postulated if the fissile materials do not completely dissolve. To determine the total plutonium and uranium content and the isotopics for cach, saltcake samples are being taken from the tank and analyzed. Other chemical and radiochemical analyses are also being carried out to provide data for planning ITP operations with salt solution prepared from this saltcake.

In March 1993, a single 1.5 inch depth saltcake sample was taken from the B-3 riser and analyzed[1]. In July 1993 three additional saltcake samples were taken. These samples were taken from the E-1 riser, which is located on the other side of the center support column of the tank from the B-3 riser. Two samples were taken on July 12 and one sample on July 13. It was . estimated that the total depth of saltcake sampled was 12 inches.

\section{EXPERIMENTAL}

The handling and analysis of the samples were performed in accordance with the requirements specified in the Task and Quality Assurance Plan[2]. During sampling, the saltcake samples taken from the E-1 riser were reported to be much more fluid than the March sample. The sample cups had been placed inside plastic sleeves. Sample cup \#2 had an additional layer of containment as it had been placed within a latex glove within the plastic sleeve. The plastic sleeve was opened and the contents of each placed onto a stainless steel tray. Liquid was observed to have leaked through the plastic sleeves into the doorstop for samples \#2 and \#3.

The total chemical and radiochemical content for each sample was determined by completely dissolving two 2.5 gram sub-samples in $2 \mathrm{M}$ nitric acid. Approximately 22.5 grams of $2 \mathrm{M}$ nitric acid were used for each dissolution. All solids were observed to dissolve with the evolution of gas bubbles. The acid solutions were divided into two portions; one portion was sent to the Analytical Services Group of SRTC and the other portion sent to the Analytical Laboratories (AL) in 772-F for determination of plutonium and uranium content and isotopics. At SRTC, the plutonium and uranium content and isotopics were determined by inductively-coupled plasma mass spectrometry (ICP/MS) and by alpha spectrometry ( $\alpha-P H A)$. At AL, the uranium and plutonium were chemically separated by ion-exchange chromatography. The plutonium content and isotopics were determined by alpha spectrometry and the uranium content and isotopics determined by thermal ionization mass spectrometry (TIMS). After completion of the uranium and plutonium analyses, the remaining chemical and radiochemical analyses were performed.

Water solubility tests were conducted in the SRTC shielded cells. Inhibited water was prepared by dissolving reagent grade sodium hydroxide in deionized, distilled water to provide a sodium hydroxide concentration of 0.015 molar. The water solubility tests consisted of weighing a . known quantity of the saltcake sample into a graduated centrifuge tube, adding increasing amounts of inhibited water, and measuring the volume of undissolved solids. After the final inhibited water addition, the sample was centrifuged, and the clear solution removed from the undissolved solids. The undissolved solids were rinsed with two small portions of inhibited water and dried at $100^{\circ} \mathrm{C}$. The dried solids were cither submitted for $\mathrm{x}$-ray diffraction analysis to identify crystalline phases present or dissolved in $2 \mathrm{M}$ nitric acid and analyzed for radiochemical and chemical composition. 
WSRC-TR-94-057

- page 3 -

January 26, 1994

During the second series of inhibited water dissolutions, it was determined that not all of the water insoluble solids dissolved in $2 \mathrm{M}$ nitric acid. A second dissolution of the remaining solids was carried out by the addition of $4 \mathrm{~mL}$ of aqua regia. Approximately $20 \%$ of the remaining solids did not dissolve in the aqua regia. The solids remaining after the aqua regia dissolution were dried at $100^{\circ} \mathrm{C}$ and stored for possible future analysis.

Blanks and standards were also analyzed along with the saltcake samples. Two blank salt solutions were used; one consisted of a simulated sait dissolved in $2 M$ nitric acid, and the second consisted of a simulated salt dissolved in inhibited water. A uranium standard solution was prepared by dissolving a simulated salt containing a known amount of uranium in $2 \mathrm{M}$ nitric acid. The blanks and uranium standard were handled in the shielded cells using the same procedures as the saltcake sample. This provided a check to determine the amount of cross contamination of the samples as a result of handling in the shielded cells. The three solutions used in the dissolutions (i.c., inhibited water, $2 \mathrm{M}$ nitric acid solution, and aqua regia solution) were also analyzed to establish a baseline for the ICP-ES resalts.

\section{RESULTS AND DISCUSSION}

\section{General Sample Characteristics and Properties}

The saltcake samples contained a mixture of light-colored, crystalline-solids and dark-colored solids. The appearance and weight of the isolated as-received samples from each cup are given in Table I. Included in Table I are the data for the March 1993 sample, which is referred to as Sample \#1-1. Sample \#2-1 referred to the first (top) sample taken in July, \#2-2 to the second (middle) sample, and \#2-3 to the third (bottom) sample.

Based on the weight of sample isolated and the volume of the sample cup, the packed densities of samples \#2-1 and \#2-3 were determined to be 0.75 and $0.66 \mathrm{~g} / \mathrm{cm}^{3}$, respectively. This is considerably lower than that determined for the March $1993 \mathrm{sample}\left(1.9 \mathrm{~g} / \mathrm{cm}^{3}\right)$. It was reported that the saltcake taken from the E-1 riser was "slushy", whereas, that from the B-3 riser was "hard like concrete"[3]. The low packed densities of the July samples are the result of liquid and/or air trapped in the sample cup.

The reported weight percent solids for sample \#2-3 is higher than the actual material, because a portion of the liquid was lost during transport to the shielded cells. No attempt was made to . recover the liquid contents in the sample because of the possible cross-contamination of the samples. Apparently, the salt in the vicinity of the E-1 tiser has a much higher liquid content than that at the B-3 riser.

Sub-samples of the damp saltcakes were dried to constant weight at $100^{\circ} \mathrm{C}$ to determine weight percent solids. The dried solids were then analyzed by $x$-ray diffraction to identify crystalline phases present. The results are presented in Table II. Sodium nitrate and sodium carbonate were the only crystalline phases identified in the as-received samples. These findings were consistent with the results of ion chromatography and ICP/ES analyses, which indicated that sodium, nitrate, and carbonate are the predominant components of the saltcake (see sections "Elemental and X-Ray Diffraction Analyses of Solids" and "Anion Analyses of Water-Soluble Solids").

The interstitial supematant liquid content of the as-received samples was estimated from the weight percent solids analysis. Assuming the weight loss upon drying to be solely due to water present in the interstitial liquid and that the interstitial liquid has a composition of that 
WSRC-TR-94-057

- page 4 -

January 26, 1994

determined for a Tank 41H supernate sample taken in October 1992 [4], the interstitial liquid in the samples was determined to range from 12 to 24 percent by weight or 17 to 35 percent by volume. The assumption that all of the weight loss is due to interstitial liquid overestimates that quantity, since some amount of water is associated with the solids as waters of hydration in the crystalline lattice. For sarmples $\$ 2-2$ and $\# 2-3$, the actual liquid content of the sample was higher than that reported above since some liquid had penetrated the plastic bags surrounding the sampling cups and was present in the doorstops.

Table I. Quantity and Appearance of Saltcake Samples

\begin{tabular}{|c|c|c|c|}
\hline$\frac{\text { Date }}{3 / 29 / 93}$ & Sample ID & $\begin{array}{l}\text { Weight (g) } \\
77.270\end{array}$ & $\begin{array}{l}\text { Appearance } \\
\text { thin layer of dark colored solids at bottom of } \\
\text { sample cup, light colored solids tightly packed in } \\
\text { remainder of sample cup }\end{array}$ \\
\hline $7 / 12 / 93$ & $\# 2-1$ & 85.169 & $\begin{array}{l}\text { mixture of light and dark colored damp solids } \\
\text { packed in sample cup }\end{array}$ \\
\hline $7 / 12 / 93$ & $\# 2-2$ & $9.308^{2}$ & $\begin{array}{l}\text { wet, slushy light and dark solids most of which } \\
\text { had leaked from sample cup }\end{array}$ \\
\hline $7 / 13 / 93$ & $\# 2-3$ & $55.835^{2}$ & $\begin{array}{l}\text { damp light and dark solids loosely packed in } \\
\text { sample cup }\end{array}$ \\
\hline \multicolumn{4}{|c|}{ - Does not include liquid found in doorstop } \\
\hline $\begin{array}{l}\text { The den } \\
\text { dissoluti } \\
\text { the addi } \\
\text { solids. } \\
\text { g/cm }{ }^{3} \text { fo } \\
\text { lower th } \\
\text { chemica }\end{array}$ & $\begin{array}{l}f \text { the as-reo } \\
\text { s. The vol } \\
\text { an aliquot } \\
\text { in these me } \\
\text { le \#2-1 an } \\
\text { determine }\end{array}$ & $\begin{array}{l}\text { saltcake so } \\
\text { f the solids } \\
\text { bited water } \\
\text { aents, the } \\
0.1 \text { g/cm } \\
\text { e March } 1\end{array}$ & $\begin{array}{l}\text { were estimated from the inhibited water } \\
\text { d total mixture were measured immediately after } \\
\text { d before significant dissolution of the saltcake } \\
\text { ities of the solids were determined to be } 1.4 \pm 0.1 \\
\text { sample } \# 2-3 \text {. These densities are considerably } \\
\text { sample }\left(1.9 \mathrm{~g} / \mathrm{cm}^{3}\right) \text {. Since, the XRD and } \\
\text { imilar, the densities of the samples should be the }\end{array}$ \\
\hline
\end{tabular}


WSRC-TR-94-057

- page 5 -

January 26, 1994

Table II. Weight Percent Solids and X-Ray Diffraction Results

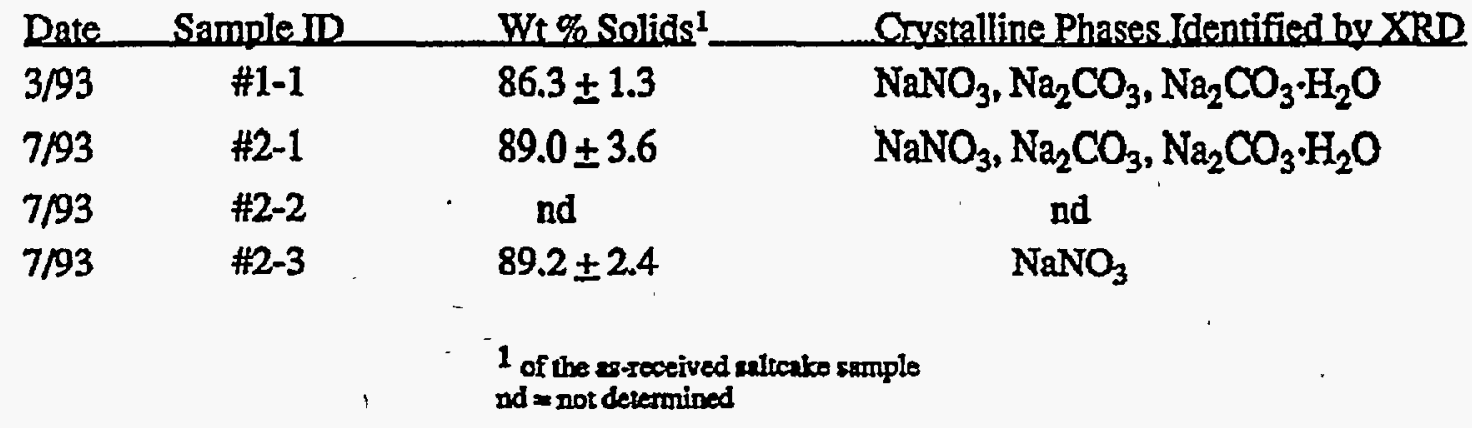

Uranium and Plutonium Content and Isotopic Abundance

Two sub-samples from each of the three as-received salteake samples were dissolved in $2 \mathrm{M}$ nitric acid and analyzed in duplicate for uranium and plutonium content and isotopics by

ICP/MS, TIMS, and $\alpha$-PHA. The average concentrations determined by ICP/MS and $\alpha-P H A$ for each mass and the total uranium and plutonium content are presented in Table III. The isotopic abundances for uranium and plutonium are presented in Table IV.

The average total uranium content of the three July samples was determined to be $4.5 \pm 1.7 \mu \mathrm{g} / \mathrm{g}$; which is very similar to that found for the March sample $(5.7 \pm 0.44 \mu \mathrm{g} / \mathrm{g})$. The uranium isotopic abundances for the March and July samples were also very similar. Since the March and July samples were taken from two different riser on opposite sides of the tank, it appears that the uranium is distributed uniformily radially in the top 12 inch layer of the tank. The similarity of the isotopic distribution in all of the samples indicates that the uranium is from the same source.

The relative standard deviation (RSD) of the total uranium content for the individual saltcake samples ranged from about 5\% to $10 \%$, whereas the RSD for the average of the three July samples was $37 \%$. At the $95.2 \%(2 \sigma)$ confidence level, the total uranium content for samples \#21 and \#2-2 are not statistically different, but are statistically different from sample \#2-3. These results suggest that there is some inhomogeneity in the distribution of the uranium in the 12 inch vertical sampling profile. Based on the July samples, the total uranium content varied by a factor of about two over the 12 inch vertical segment.

The average total plutonium content of the July samples was determined to be $0.033 \pm 0.0081$ $\mu \mathrm{g} / \mathrm{g}$, which is about half of that found in the March sample $(0.065 \pm 0.0098 \mu \mathrm{g} / \mathrm{g})$. The average Pu-238 and Pu-239 abundances were determined to be considerably different for the March and

July samples. However, at the $95.2 \%(2 \sigma)$ confidence level, there was no statistically significant differences between the March and July samples because of the greater uncertainty in the March sample results.

The RSDs of the total plutonium content ranged from about $3 \%$ to $23 \%$ for the individual samples compared to that of $25 \%$ for the average of the three July samples. The higher RSDs for plutonium, compared to the uranium values, were attributed to the lower plutonium

concentration and the higher analytical uncertainty for the $\alpha$-PH.A measurement. Because of the 
WSRC-TR-94-057

- page 6 -

January 26, 1994

similarity in the RSDs for the individual and average samples, it cannot be determined if there was any difference in vertical distribution of plutonium.

The factor of two difference in the plutonium content between the March and July samples is atributed to the difference in the amount of water-insoluble solids. For both the March and July samples, $95 \%$ or more of the total plutonium in the saltcake samples is associated with the insoluble solids fraction (see section "Determination of Water Soluble and Insoluble Uranium and Plutonium Content"). The quantity of insoluble solids in the July samples was about onehalf of that found in the March sample. Thus, it follows that the lower plutonium content is due to the lower insoluble solids content in the July samples.

From the ICP/MS data, the average weight ratio of Pu-239/240 was 4.9 for the three July samples. This is lower than the ratio of 6.9 found for the March sample. The weight ratio of Pu$239 / 240$ for heat-source plutonium is 7.0 and for weapons-grade plutonium is 16 . The measured weight ratios for the March and July samples were closer to that for heat-source plutonium, which is consistent with H-canyon processing. H-canyon waste would be the principal contributor to the waste stored in this tank.

Table III. Uranium and Plutonium Content

\begin{tabular}{|c|c|c|c|c|c|c|}
\hline \multirow[b]{2}{*}{ Mass } & \multicolumn{6}{|c|}{ Average Concentration $(\mu g / g) 1$} \\
\hline & $\# 1-1$. & \#2-1. & \#2-2 & \#2-3 & Are, \#2 & $\%$ RSD \\
\hline $\mathrm{U}-233$ & $2.7 \pm 0.14 \mathrm{E}-02$ & $2.3 \pm 0.73 \mathrm{E}-02$ & $1.7 \pm 0.79 \mathrm{E}-02$ & $9.6 \pm 4.2 \mathrm{E}-03$ & $1.7 \pm 0.69 \mathrm{E}-02$ & 41 \\
\hline $\mathrm{J}-234$ & $2.5 \pm 0.18 \mathrm{E}-01$ & $2.5 \pm 0.38 \mathrm{E}-01$ & $2.0 \pm 0.22 \mathrm{E}-01$ & $1.1 \pm 0.11 \mathrm{E}-01$ & $1 . \dot{9} \pm 0.69 \mathrm{E}-01$ & 36 \\
\hline $\mathrm{J}-235$ & $7.5 \pm 0.52 \mathrm{E}-01$ & $6.8 \pm 1.4 E-01$ & $5.5 \pm 0.84 E-01$ & $3.1 \pm 0.48 \mathrm{E}-01$ & $5.1 \pm 1.9 \mathrm{E}-01$ & 37 \\
\hline $\mathrm{J}-236$ & $2.8 \pm 0.20 \mathrm{E}-01$ & $2.6 \pm 0.51 \mathrm{E}-01$ & $2.1 \pm 0.32 \mathrm{E}-01$ & $1.1 \pm 0.17 \mathrm{E}-01$ & $1.9 \pm 0.72 E-01$ & 138 \\
\hline $\mathrm{J} \cdot 238$ & $4.4 \pm 0.35 E+\infty 0$ & $4.8 \pm 0.39 E+00$ & $3.9 \pm 0.11 E+00$ & $2.1 \pm 0.070 \mathrm{E}+00$ & $3.6 \pm 1.3 E+00$ & 136 \\
\hline otal U & $5.7 \pm 0.44 E+00$ & $6.0 \pm 0.63 E+00$ & $4.8 \pm 0.25 \mathrm{E}+00$ & $2.7 \pm 0.15 \ddot{E}+00$ & $4.5 \pm 1.7 \mathrm{E}+00$ & 38 \\
\hline$u-238$ & $3.8 \pm 0.45 \mathrm{E}-02$ & $2.0 \pm 0.13 E-02$ & $3.3 \pm 0.69 \mathrm{E}-02$ & $2.3 \pm 0.15 E-02$ & $2.5 \pm 0.67 \mathrm{E}-02$ & 27 \\
\hline $4-239$ & $2.3 \pm 0.15 \mathrm{E}-02$ & $5.3 \pm 1.6 \mathrm{E}-03$ & $7.6 . \pm 1.6 \mathrm{E}-03$ & $5.1 \pm 1.5 \mathrm{E}-03$ & $6.0 \pm 1.4 \mathrm{E}-03$ & 23 \\
\hline$u-240$ & $3.3 \pm 0.45 \mathrm{E}-03$ & $1.1 \pm 0.30 \mathrm{E}-03$ & $1.5 \pm 0.95 \mathrm{E}-03$ & $1.0 \pm 0.25 \mathrm{E}-03$ & $1.2 \pm 0.26 \mathrm{E}-03$ & 322 \\
\hline$u-241$ & $6.7 \pm 1.1$ E-04 & $2.3 \pm 3.3 \mathrm{E}-04$ & $3.3 \pm 2.4 \mathrm{E}-04$ & $3.4 \pm 0.60 \mathrm{E}-04$ & $3.0 \pm 0.61 \mathrm{E}-04$ & 420 \\
\hline$u-242$ & $3.7 \pm 1.1$ E-04 & $1.2 \pm 0.41$ E-0.4 & $1.0 \pm 0.67$ E-05 & $2.0 \pm 1.7$ E-04 & $1.1 \pm 0.95 \mathrm{E}-04$ & 87 \\
\hline tal Pu & $6.5 \pm 2.5 \mathrm{E}-02$ & $2.7 \pm 0.085 \mathrm{E}-02$ & $4.2 \pm 0.97 \mathrm{E}-02$ & $2.9 \pm 0.27 E-02$ & $3.3 \pm 0.81 \mathrm{E}-02$ & 25 \\
\hline 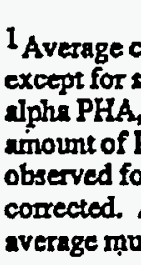 & ins & w & atson & tre pe & $0 \times r$ & $\begin{array}{l}\text { scid. } \\
\text { ined by } \\
\text { a, the } \\
\text { nee } \\
\pi\end{array}$ \\
\hline
\end{tabular}


WSRC-TR-94-057

- page 7 -

January 26, 1994

Table IV. Uranium and Plutonium Isotopic Abundances

\begin{tabular}{|c|c|c|c|c|c|c|}
\hline \multirow[b]{2}{*}{ Isotope } & \multicolumn{6}{|c|}{ Abundance $(\%)^{1}$} \\
\hline & \#1-1. & \#2-1. & \#2-2. & \#2-3 & Are\#2 & $\%$ RSD \\
\hline U-233 & $0.48 \pm 0.17$ & $0.37 \pm 0.082$ & $0.35 \pm 0.15$ & $0.36 \pm 0.14$ & $0.37 \pm 0.020$ & 5.5 \\
\hline U-234 & $4.3 \pm 0.064$ & $4.1 \pm 0.21$ & $4.1 \pm 0.25$ & $4.2 \pm 0.18$ & $4.1 \pm 0.058$ & 1.4 \\
\hline$U-235$ & $13 \pm 1.8$ & $11 \pm 1.1$ & $11 \pm 12$ & $11 \pm 12$ & $11 \pm 0.0$ & 0 \\
\hline$U-236$ & $5.0 \pm 0.071$ & $4.3 \pm 0.41$ & $4.3 \pm 0.43$ & $4.3 \pm 0.40$ & $4.3 \pm 0.0$ & 0 \\
\hline$U-238$ & $77 \pm 0.32$ & $80 \pm 1.8$ & $80 \pm 2.0$ & $80 \pm 1.9$ & $80 \pm 0.0$ & 0 \\
\hline$P(2-238$ & $58 \pm 23$ & $75 \pm 5.6$ & $78 \pm 24$ & $77 \pm 8.7$ & $\therefore 77 \pm 1.5$ & 2.0 \\
\hline Pu-239 & $35 \pm 14$ & $20 \pm 6.1$ & $18 \pm 5.7$ & $17 \pm 4.4$ & $18 \pm 1.5$ & 8.3 \\
\hline $\mathrm{Pu}-240$ & $5.1 \pm 2.1$ & $4.1 \pm 1.1$ & $3.6 \pm 2.4$ & $3.5 \pm 0.89$ & $3.7 \pm 0.32$ & 8.6 \\
\hline $\mathrm{Pu}-241$ & $1.0 \pm 0.43$ & $0.87 \pm 1.2$ & $0.78 \pm 0.59$ & $1.2 \pm 0.23$ & $0.95 \pm 0.22$ & 23 \\
\hline $\mathrm{Pu}-242$ & $0.57 \pm 0.39$ & $0.45 \pm 0.16$ & $0.025 \pm 0.017$ & $0.69 \pm 0.58$ & $0.39 \pm 0.34$ & 87 \\
\hline
\end{tabular}

${ }^{1}$ Average values for the ns-seceived sumple from duplicate measurements of two different dissohutions in nitric reid. except for sumple \#1-1 for which duplicate measurements of five different dissolutions were performed. Pa-238 determined by alphs PHA, all other itotopes determined by ICR/MS. U-238 also includes Pu-238. From the ilpha spectrometry reanits, the umount of Pu238 is between $0.4-1.4 \%$ by weight of the total meastred at mass 238. These values yre less then the variance observed for the duplicate analyses of replicare aub-amples, and therefore, the corresponding U-238 values have not been corrected. Average " 2 equals the averuge of sarples \$2-1, \$2-2, and \$2-3. \% RSD equals the standurd deviation divided by the average multiplied by 100 .

The TIMS method analytical results for the uranium content and isotopics are presented in Table V. The average total uranium content as determined by the TIMS method for the thire samples taken in July $1993(1.3 \mu \mathrm{g} / \mathrm{g})$ is approximately a factor of three lower than that determined by ICPMS $(4.5 \mu \mathrm{g} / \mathrm{g})$. This is in contrast to the March 1993 sample, where the TIMS result was slightly higher than the ICP/MS result. The variance in the TIMS results suggests that the uranium may not be distributed uniformily radially, which is in contrast to the conclusion suggested by the ICP/MS results.

At the $95.2 \%(2 \sigma)$ confidence level, the total uranium contents for the three July samples as determined by TIMS were not statistically different. The RSDs for the individual total uranium contents of the four samples were equal to or greater than the RSD determined for the average of the three July samples. From the TIMS results, there was no evidence for a non-uniform distribution of uranium in the vertical sampling profile. The greater variation in the TIMS method results compared to the ICP/MS method is attributed to the additional sample preparation steps required for the separation of uranium prior to the TIMS determination. 
WSRC-TR-94-057

- page 8 -

January 26, 1994

A synthetic saltcake material containing uranium of known content $(2.46 \mu \mathrm{g} / \mathrm{g})$ was analyzed at the same time as the other samples as a quality assurance check. The total uranium concentration determined by the ICP/MS method was $2.62 \pm 0.0497 \mu \mathrm{g} / \mathrm{g}$ and $2.78 \mathrm{\mu g} / \mathrm{g}$ by the TMMS method. The slightly higher result by the ICP/MS method may be indicative of a small bias of between 4 and 8 percent for this method. For the TIMS method, the bias was $13 \%$ which is higher than that for the ICP/MS method. Based on the results of the uranium standard material, it is concluded that the uranium results for the Tank $41 \mathrm{H}$ saltcake are valid for both methods. For nuclear safety assessments, it is recommended that the higher ICPMS result be used since this would conservatively overestimate the total amount of fissile uranium in the saltcake.

Table V. Thermal Ionization Mass Spectrometric Results for Uranium Content and Isotopic Abundances

\section{Concentration $(\mu g / g)$}

\begin{tabular}{lllllll} 
Sample & $\# 1-1$ & $\# 2.1$ & $\# 2-2$ & $\# 2-3$ & \multicolumn{2}{c}{ Ave.\#2 \%RSD } \\
Total U (TIMS) & $7.8 \pm 1.8$ & $1.5 \pm 0.74$ & $1.4 \pm 0.42$ & $1.0 \pm 0.24$ & $1.3 \pm 0.2519$ \\
Tow U (ICP/MS) & $5.7 \pm 0.44$ & $6.0 \pm 0.63$ & $4.8 \pm 0.25$ & $2.7 \pm 0.15$ & $4.5 \pm 1.7$ & 38
\end{tabular}

\begin{tabular}{lllllll} 
& \multicolumn{9}{c}{ Abundance (\%) } \\
Sample & \#1-1 & \#2.1 & \#2.2 & \#2-3 & AYe.\#2 \%RSD \\
U-234 & $3.4 \pm 0.87$ & $2.7 \pm 0.18$ & $2.2 \pm 0.64$ & $2.3 \pm 1.5$ & $2.4 \pm 0.2611$ \\
U-235 & $7.9 \pm 1.6$ & $7.6 \pm 2.7$ & $6.3 \pm 1.8$ & $6.4 \pm 3.9$ & $6.8 \pm 0.7211$ \\
U-236 & $3.4 \pm 0.60$ & $3.0 \pm 0.086$ & $2.3 \pm 0.70$ & $2.4 \pm 1.6$ & $2.6 \pm 0.3815$ \\
U-238 & $85 \pm 2.8$ & $87 \pm 3.6$ & $89 \pm 3.1$ & $89 \pm 7.0$ & $88 \pm 1.2$ & 1.4
\end{tabular}

Average \#2 equals the average of emples $\$ 2-1, \# 2-2$, and \#2-3. \% RSD equals the standind deviation divided by the average multiplied by 100.

\section{Other Actinides}

The ICP/MS data included masses 237,243 and 244 . These masses should be primarily due to neptunium-237, americium-243 and curium-244. The analytical results for these actinides are presented in Table VI. After correcting for the salt blank, the amounts of americium-243 and curium-244 were very low. The low americium and curium content was also confirmed by $\gamma$-PHA and $\alpha$-PHA analyses.

The americium-241 content of the water-soluble solids fraction of sample \#2-1was $\leq 7.0 \mathrm{E}-04$ $\mu \mathrm{g} / \mathrm{g}$ and $\leq 4.8 \mathrm{E}-02$ for sample \#2-3. The curium-244 content of the water-soluble fraction of sample \#2-1 was $3.2 \pm 2.8 \mathrm{E}-05 \mathrm{\mu g} / \mathrm{g}$ and $<6.2 \mathrm{E}-06 \mu \mathrm{g} / \mathrm{g}$ for sample \#2-3. There was no detectable americium-243 or curium-244 in the ICP/MS analyses of the \#2-1 or \#2-3 insoluble solids fractions. Based on the analysis of the water soluble and insoluble fractions, all of the curium-244 appears to be water soluble. In contrast, most or all of the neptunium-237 appeared to be associated with the insoluble solids fraction. This was unexpected since neptunium is 
WSRC-TR-94-057

- page 9 .

January 26, 1994

reported to have an equal or greater solubility than uranium in alkaline salt solutions[5]. A possible explanation of the low solution concentration is that the neptunium is adsorbed by the insoluble solids.

Table VI. ICP/MS Results for Other Actinides

Concentration $(\mu \mathrm{g} / \mathrm{g})^{1}$

Samnle

\#1-1

\#2-1

\#2-2

\#2-3

Neptunium-237

$0.163 \pm 0.0043 \quad 0.058 \pm 0.013$

$0.14 \pm 0.023$

$0.065 \pm 0.010$

Americium-243

$5.8 \pm 13 \mathrm{E}-05$

$3.3 \pm 3.1 \mathrm{E}-05$

$1.9 \pm 2.6 \mathrm{E}-04$

$1.2 \pm 1.0 \mathrm{E}-04$

Curium-244

$3.2 \pm 3.2 \mathrm{E}-05$

$9.7 \pm 9.1 \mathrm{E}-0.05$

$3.2 \pm 3.4 \mathrm{E}-05$

$2.4 \pm 0.32$ E-04

${ }^{1}$ Average concentrations for the es-received semple from duplicate ICP/MS mearurements of two different dissolutions in nirric acid except for sample \#1-1 for which duplicate measurements of five different dissolutions were performed.

Characterization of Water Insoluble Solids

Dark solids were observed in all three of the July samples as well as the earlier March sample. As found in the March sample, these solids do not dissolve in inhibited water. The quantity of insoluble solids was determined for each sample and is presented in Table VII. The amount of dark solids in the July samples was about half of that found in the March sample. Two separate inhibited water dissolutions were carried out for samples \#2-1 and \#2-3. Because of the limited quantity of the \#2-2 sample, no inhibited water dissolutions were conducted with this sample.

The dark-colored, water-insoluble solids settled rapidly from the salt solutions produced by dissolving the saltcake samples in inhibited water. Within 60 minutes, the majority of the solids had settled to the bottom of the container. After standing overnight, all of the solids had settled to the bottom of the container producing a clear solution with no suspended solids.

One of the two dried samples for each of the first set of dissolutions was submitted for XRD analysis. The crystalline phases identified in these two samples are reported in Table VII. Sodium nitrate was found in all the samples anialyzed by XRD. The other crystalline phases found included sodium aluminum silicate, zinc sodium phosphate, sodium fluorophosphate, and zinc sodium silicate. The composition of the dark solids is not identical for all samples indicating some degree of heterogeneity for the insoluble solids among the axial and $12 \mathrm{inch}$ vertical profiles.

The second sample from the first dissolution set and both sarmples from the second dissolution set were dissolved in $2 \mathrm{M}$ nitric acid for chemical and radiochemical analysis. The nitric acid' dissolution of the first set was carried out in the Shielded Cells and the second set in laboratory module B-126/130 of 773-A. All of the dark solids appeared to dissolve for the first set in the Shielded Cells. In the dissolutions carried out in B-126/130, not all of the solids dissolved. After contacting with nitric acid, the remaining undissolved solids were light tan in color. Because of the small quantity of material and the poorer visibility in the Shielded Celis the light colored solids may also have been present, but not identified in the first dissolution tests. 
WSRC-TR-94-057

- page 10 -

January 26, 1994

After contacting with nitric acid, the undissolved solids were treated with aqua regia $\left(3 \mathrm{HCl} / \mathrm{HNO}_{3}\right)$. Some but not all of the remaining solids dissolved in the aqua regia. It is estimated that about 5-15\% of the water insoluble solids did not dissolve in the nitric acid or the aqua regia. Based on the low solubility in nitric acid and aqua regia, these solids may be silica and/or aluminosilicates. These materials are known to have low solubility in these acids.

The distribution of the water-insoluble solids in sample \#2-1 does not appear to be uniform based on the large difference in the quantity of insoluble solids between the two separate dissolution sets. From the first dissolution set, the quantity of insoluble solids was determined to be $0.89 \pm$ $0.11 \mathrm{wt} \%$, and from the second dissolution set, the quantity was $0.13 \pm 0.0064 \mathrm{wt} \%$. For sample \#2-3, the variation between dissolution sets was much smaller, perhaps indicating a more . uniform distribution.

Upon dissolution of the Tank $41 \mathrm{H}$ saltcake for processing in Tank 48H, there will be insoluble solids. Based on the soluble sodium concentration and the insoluble solids content determined for the March and July samples, the concentration of insoluble solids in the redissolved salt solution is calculated to range from 580 to $7900 \mathrm{mg} / \mathrm{L}$ at a sodium ion concentration of $5.2 \mathrm{M}$. Process requirements for ITP currently limit the insoluble solids content to $400 \mathrm{mg} / \mathrm{L}$ [6]. Thus, the insoluble solids content in the redissolved salt solution may exceed the current limit. The insoluble solids limit is provided to minimize possible impacts on filter performance by insoluble solids other than monosodium titanate and tetraphenylborate salts. Removal of the insoluble solids from the redissolved salt solution may be required to prevent any impact on the performance of the ITP filters.

Table VII. Solids Content and Crystalline Phases of the Dark Solids Wt \% Solids

Sample ID $\# 1-1$

\#2-1

Diss. \#1

Diss. \#2

Average

\#2-3

Diss. \#1

Diss. \#2

Average
Wet Basis 1

$1.7 \pm 0.026$

Dry Basis 2

$2.0 \pm 0.026$

\author{
XRD Results \\ $\mathrm{Na}_{8}\left(\mathrm{Al}_{6} \mathrm{Si}_{6} \mathrm{O}_{24}\right)\left(\mathrm{NO}_{3}\right)_{2} \cdot 4 \mathrm{H}_{2} \mathrm{O}$ \\ $\mathrm{NaNO}_{3}$, \\ $\mathrm{Zn}_{2} \mathrm{NaP}_{3} \mathrm{O}_{16} \cdot 9 \mathrm{H}_{2} \mathrm{O}$
}


WSRC-TR-94-057

- page 11 -

January 26, 1994

Determination of Water-Soluble and Insoluble Uranium and Plutenium Content

The uranium and plutonium content of the water soluble and insoluble solids is given in Table VIII. From the ICP/MS data, there was no detectable plutonium in the soluble fraction of the July samples, indicating all of the plutonium was associated with the insoluble solids. AlphaPHA spectrometry indicated that the soluble solids did have a small amount of plutonium activity. It is estimated that no more than $5 \%$ of the total plutonium present in the July saltcake samples was associated with or remained in the dissolved salt solution.

The percent of the total uranium and plutonium in the water-soluble and water-insoluble fractions as well as mass balances for plutonium and uranium are provided in Table IX. These results were consistent with March sample which found that $4.7 \%$ of the plutonium and $89 \%$ of the uranium are present in the water soluble crystalline solids. Although the percent soluble. uranium for sample \#2-3 (64\%) was lower than that for samples \#1-1 and \#2-1, it was not statistically different because of the higher analytical uncertainty.

Comparing the measured total uranium and plutonium content for the saitcake sample to that based on the analysis of the two fractions indicated a fairly good mass balance for plutonium and uranium. The calculated range of total uranium and plutonium concentrations for samples \#2-1 and \#2-3, calculated as the sum of the soluble and insoluble solids concentrations, were all within the $95.2 \%(2 \sigma)$ confidence interval determined from the total sample dissolutions in nitric acid. There was no detectable uranium and plutonium in any of the aqua regia dissolutions. This confirmed that the all of the uranium and plutonium in saltcake samples was measured upon dissolution of the samples in $2 \mathrm{M}$ nitric acid. 
WSRC-TR-94-057

- page 12 -

January 26, 1994

Table VII. Uranium and Plutonium Content and Isotopic Abundances of Soluble and Insoluble Solids ${ }^{1}$

\section{Sample \#2-1}

Soluble Solids ${ }^{2}$

Insoluble Solids 3

$\begin{array}{lcccc}\text { Mass } & \text { Conc. (ug/g) } & \text { \% Abundance } & \text { Conc. }(u g / g) & \text { \% Abundance } \\ 233 & 0 & 0 & 0.3 \pm 0.89 & 0.36 \pm 0.18 \\ 234 & 0 & 0 & 25 \pm 7.9 & 4.1 \pm 1.8 \\ 235 & 0.36 \pm 0.013 & 9.7 \pm 0.20 & 67 \pm 23 & 11 \pm 5.2 \\ 236 & 0.063 \pm 0.0017 & 1.7 \pm 0.074 & 26 \pm 8.5 & 4.2 \pm 1.9 \\ 238 & 3.3 \pm 0.048 & 89 \pm 0.13 & 500 \pm 160 & 81 \pm 37 \\ \text { Total U } & 3.7 \pm 0.060 & 100 & 620 \pm 200 & 100 \\ & & 0 & 8.8 \pm 0.82 & 75 \pm 9.9 \\ 238 & 0 & 0 & 2.6 \pm 0.12 & 22 \pm 2.3 \\ 239 & 0 & 0 & 0.31 \pm 0.097 & 2.6 \pm 0.85 \\ 240 & 0 & 0 & 0.057 \pm 0.054 & 0.46 \pm 0.44 \\ 241 & 0 & 0 & 0 & 0 \\ 242 & 0 & 0 & 11.8 \pm 1.1 & 100\end{array}$

Sample \#2-3

Soluble Solids ${ }^{2}$

Insoluble Solids ${ }^{3}$

\begin{tabular}{|c|c|c|c|c|}
\hline $\begin{array}{l}\text { Mass } \\
233 \\
234 \\
235 \\
236 \\
238 \\
\text { Total U }\end{array}$ & $\begin{array}{l}\text { Conc }(\mu g / g) \\
0 \\
0 \\
0.10 \pm 0.019 \\
0 \\
1.3 \pm 0.31 \\
1.4 \pm 0.32\end{array}$ & $\begin{array}{l}\% \text { Abundance } \\
0 \\
0 \\
7.2 \pm 0.32 \\
0 \\
93 \pm 0.32 \\
100\end{array}$ & $\begin{array}{l}\text { Conc. }(\mu \mathrm{g} / \mathrm{g}) \\
0.35 \pm 0.021 \\
3.9 \pm 0.033 \\
11 \pm 0.096 \\
3.9 \pm 0.046 \\
79 \pm 1.2 \\
98 \pm 1.4\end{array}$ & $\begin{array}{l}\text { \% Abundance } \\
0.36 \pm 0.022 \\
4.0 \pm 0.066 \\
11 \pm 0.18 \\
4.0 \pm 0.074 \\
81 \pm 1.7 \\
100\end{array}$ \\
\hline $\begin{array}{l}238 \\
239 \\
240 \\
241 \\
242 \\
\text { Total Pu }\end{array}$ & $\begin{array}{l}0 \\
0 \\
0 \\
0 \\
0 \\
0\end{array}$ & $\begin{array}{l}0 \\
0 \\
0 \\
0 \\
0 \\
0\end{array}$ & $\begin{array}{l}2.7 \pm 0.42 \\
0.66 \pm 0.038 \\
0.080 \pm 0.046 \\
0.018 \\
0 \\
3.46 \pm 0.50\end{array}$ & $\begin{array}{l}78 \pm 17 \\
19 \pm 3.0 \\
2.3 \pm 0.59 \\
0.52 \\
0 \\
100\end{array}$ \\
\hline
\end{tabular}

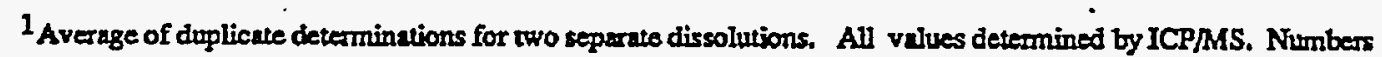
in parentheris re the $1 \sigma$ values for the stundurd deviation.

2 Soluble solids equais weight of as-received saltcake minus weight of dried insoluble solids.

3 Average of duplicate determinations for two separate discolutions. 


\section{WSRC-TR-94-057 \\ - page 13 - \\ January 26, 1994}

Table IX. Uranium and Plutonium Concentration in Soluble and Insoluble Solids, Mass Balance and Percent of Total Content

Concentration and \% of Total

\#1-1

\#2-1

\#2-3

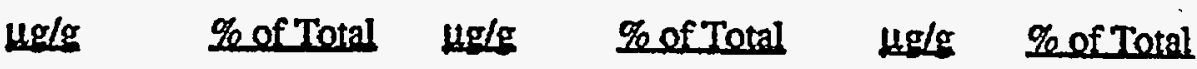

$\begin{array}{lllllll}\text { Soluble U } & 4.68 \pm 0.05 & 89 & 3.7 \pm 0.060 & 82 \pm 2 & 1.4 \pm 0.32 & 63 \pm 20 \\ \text { Insoluble U } & 32.8 \pm 0.9 & 11 & 620 \pm 200 & 18 \pm 0.43 & 98 \pm 1.4 & 37 \pm 12 \\ \text { Soluble } \mathrm{Pu} & 1.24 \pm 0.24 \mathrm{E}-3 & 4.7 & 0 & 0 & 0 & 0 \\ \text { Insoluble } \mathrm{Pu} & 1.45 \pm 0.04 & 95 & 11.8 \pm 1.1 & 100 & 3.46 \pm 0.50 & 100\end{array}$

\section{Mass Balance}

\#1-1

낭

Calc. Ave. U

Meas. Ave. U

Calc. $2 \sigma$ Range .

Meas. 2 $\sigma$ Range

Calc. Ave. Pu

Meas. Ave. Pu

Calc. 20 Range

Meas. 20 Range
$5.16 \pm 0.4$

$5.66 \pm 0.28$

5.1-5.2

$5.1-6.2$

$0.026 \pm 0.0026$

$0.027 \pm 0.0016$

0.021-0.031

0.024-0.031
\#2-1

$4 \mathrm{~g} / \mathrm{g}$

$4.5 \pm 0.090$

$6.0 \pm 0.63$

4.3-4.7

4.7-7.3

$0.016 \pm 0.0014$

$0.027 \pm 0.0085$

0.013-0.019

$0.010-0.044$
\#2-3

$\mu \mathrm{g} / \mathrm{g}$

$2.2 \pm 0.50$

$2.7 \pm 0.15$

1.2-3.2

2.4-3.0

$0.029 \pm 0.0042$

$0.029 \pm 0.0027$

0.021-0.037

$0.024-0.034$

Concentrations are those determined by ICPMS and do not inclnde Pu-238 content as determined by $\alpha$-PHA. Numbers in parentheris tre the $1 \sigma$ valves for the stunderd deveintions. Range at $2 \sigma$ is calculated by subtracting and adding two tines the stemdard deviution to the average concentration. Percent of total is the calculated by dividing the proxtuct of the fractional plutonium or uranium concentration and the total fractional weight concentration by the total calculated quantity of plutonium or urenium. Calculuted average concentration is the num of the sohble and insolpbie concentrations multiplied by the respective weight fractions. Measured concentrations are those determined from the nitric scid dissolution of the at-received salteake sumples.

Elemental and X-ray Diffraction Analyses of Solids

The elemental compositions of the as-received samples, the water-soluble fractions, and the water-insoluble fractions were determined by ICP-ES and atomic absorption spectroscopic (AA) analytical methods. The results for the March sample and the three July samples are presented in Appendices 1-4.

The predominant elements found in the as-received samples included $\mathrm{Na}, \mathrm{P}$ and $\mathrm{Al}$, with smaller amounts of $\mathrm{Zn}, \mathrm{Cr}$, and $\mathrm{K}$. The results for each of these elements for the March and July samples are presented in Table $X$. For the as-received samples, three solid phases were identified from 
WSRC-TR-94-057

- page 14 -

January 26, 1994

the XRD patterns: sodium nitrate $\left[\mathrm{NaNO}_{3}\right]$, sodium carbonate $\left[\mathrm{Na}_{2} \mathrm{CO}_{3}\right]$ and hydrated sodium carbonate $\left[\mathrm{Na}_{2} \mathrm{CO}_{3} \cdot \mathrm{xH}_{2} \mathrm{O}\right]$. The identification of these salts was consistent with the chemical analysis that found sodium, nitrate and cartonate comprised almost $80 \mathrm{wt} \%$ of the as-received samples.

The potassium:sodium (K:Na) weight ratio in the soluble fraction of the saltcake sample was determined to be 0.0013 for sample \#1-1, 0.00052 for sample \#2-1, and 0.00074 for sample $\$ 2-3$. Thus, concentrated salt solutions prepared having these $\mathrm{K}: \mathrm{Na}$ ratios would have a potassium concentrations of $0.0048 \mathrm{M}(\# 1-1), 0.0019 \mathrm{M}(\# 2-1)$, and $0.0023 \mathrm{M}(\# 2-3)$ at a $\mathrm{Na}+$ concentration of 6.3M. These potassium concentrations range from a factor of 3.8 to 9.5 lower than that reported for average concentrated salt solution[7]. Consequently, much less potassium tetraphenylborate precipitate $(-10-25 \%)$ would be produced from salt solution resulting from the dissolution of Tank $41 \mathrm{H}$ saltcake having the $\mathrm{K}: \mathrm{Na}$ ratios measured in these samples.

The water-insoluble solids were found to contain $\mathrm{Na}, \mathrm{Zn}, \mathrm{Cr}, \mathrm{P}, \mathrm{Al}, \mathrm{Fe}, \mathrm{Ca}$, and $\mathrm{Si}$. The concentration of the predominant elements are presented in Table XI. These results were consistent with $x$-ray diffraction results that indicated the presence of a number of crystalline phases including sodium aluminum silicate, sodium zinc phosphate, sodium fluorophosphate, and sodium zinc silicate. Chromium, iron, and calcium apparently were present as amorphous solids.

Table X. Major Elemental Concentrations Found in Total Sample

\section{Weight \%}

\begin{tabular}{cllllll} 
Element & $\# 1-1$ & $\# 2.1$ & $\# 2=2$ & $\# 2-3$ & Are.\#2 & \%RSD \\
\hline $\mathrm{Na}$ & $28.0 \pm 0.57$ & $27.9 \pm 1.6$ & $26.6 \pm 0.80$ & $27.3 \pm 0.38$ & $27.3 \pm 0.65$ & 2.4 \\
$\mathrm{Al}$ & $0.21 \pm 0.016$ & $0.11 \pm 0.020$ & $0.25 \pm 0.058$ & $0.10 \pm 0.048$ & $0.15 \pm 0.084$ & 56 \\
$\mathrm{P}$ & $0.41 \pm 0.040$ & $0.37 \pm 0.090$ & $0.43 \pm 0.16$ & $0.33 \pm 0.060$ & $0.38 \pm 0.050$ & 13 \\
$\mathrm{Zn}$ & $0.059 \pm 0.015$ & $0.014 \pm 0.0023$ & $0.21 \pm 0.064$ & $0.069 \pm 0.031$ & $0.098 \pm 0.10$ & 100 \\
$\mathrm{Cr}$ & $0.058 \pm 0.0036$ & $0.092 \pm 0.021$ & $0.079 \pm 0.022$ & $0.058 \pm 0.014$ & $0.076 \pm 0.017$ & 22 \\
$\mathrm{~K}$ & $0.032 \pm 0.0001$ & $0.019 \pm 0.0024$ & $.0 .031 \pm 0.0074$ & $0.024 \pm 0.0028$ & $0.025 \pm 0.006$ & 24
\end{tabular}

2 Average concentrations and standand deviations (10) of as-received samples. Average $\# 2$ equals the average of sumples \#2-1, \#2-2, and \#2-3. \% RSD equals the standard deviation divided by tho average multiplied by 100. 
WSRC-TR-94-057

- page 15 -

January 26, 1994

Table XI. Major Elemental Concentrations Found in Water-Soluble Solids

\section{Weight \%a}

\begin{tabular}{cllllll} 
Element & \#1-L & \multicolumn{1}{c}{ \#2-1 } & \#2-2 & \multicolumn{1}{c}{ \#2-3 } & \multicolumn{1}{c}{ Ave.\#2 } & \%RSD \\
$\mathrm{Na}$ & 25.8 & $27.0 \pm 1.2$ & nd & $27.1 \pm 1.2$ & $27.1 \pm 0.071$ & 0.26 \\
$\mathrm{Al}$ & 0.21 & $0.093 \pm 0.0050$ & nd & $0.095 \pm 0.057$ & $0.094 \pm 0.0014$ & 1.5 \\
$\mathrm{P}$ & 0.37 & $0.34 \pm 0.0024$ & nd & $0.25 \pm 0.073$ & $0.30 \pm 0.064$ & 22 \\
$\mathrm{Zn}$ & 0.040 & $0.0021 \pm 0.0011$ & nd & $0.026 \pm 0.030$ & $0.014 \pm 0.017$ & 120 \\
$\mathrm{Cr}$ & 0.0088 & $0.021 \pm 0.0032$ & nd & $0.0068 \pm 0.0010$ & $0.014 \pm 0.010$ & 72 \\
$\mathrm{~K}$ & 0.034 & $0.014 \pm 0.0043$ & nd & $0.020 \pm 0.0011$ & $0.017 \pm 0.0042$ & 25
\end{tabular}

Average concentrations md standard devintions (10) of as-received samples.

Average \#2 equals the average of amples $* 2-1, * 2-2$, and $\$ 2-3,90$ RSD equals the standard deviation divided by the average multiplied by 100 .

$n d=$ not determined

Table XII. Elemental Composition of Insoluble Solids Fraction

\begin{tabular}{clllllll} 
& \multicolumn{5}{c}{ Weight \%a } \\
Element & \#1-1 & \multicolumn{1}{c}{ \#2-1 } & \#2-2 & \#2-3 & Are.\#2 & \% BSD \\
$\mathrm{Na}$ & 8.5 & $23.2 \pm 0.12$ & nd & $23.9 \pm 0.25$ & $23.6 \pm 0.49$ & 2.1 \\
$\mathrm{Al}$ & 0.62 & $0.66 \pm 0.015$ & nd & $0.48 \pm 0.016$ & .0 & $0.57 \pm 0.13$ & 23 \\
$\mathrm{P}$ & 0.90 & $0.92 \pm 0.028$ & nd & $7.0 \pm 0.12$ & $4.0 \pm 4.3$ & 110 \\
$\mathrm{Zn}$ & 2.8 & $1.2 \pm 0.011$ & nd & $3.2 \pm 0.054$ & $2.2 \pm 1.4$ & 64 \\
$\mathrm{Cr}$ & 2.4 & $5.7 \pm 0.051$ & nd & $3.9 \pm 0.081$ & $4.8 \pm 1.3$ & 27 \\
$\mathrm{Ca}$ & 0.40 & $2.8 \pm 0.050$ & nd & $2.2 \pm 0.036$ & $2.5 \pm 0.42$ & 17 \\
$\mathrm{Mg}$ & 0.011 & $0.039 \pm 0.00046$ & nd & $0.033 \pm 0.00024$ & $0.036 \pm 0.0042$ & 12 \\
$\mathrm{Fe}$ & 0.55 & $2.3 \pm 0.020$ & nd & $7.0 \pm 0.12$ & $4.7 \pm 3.3$ & 70 \\
$\mathrm{Si}$ & 0.24 & $0.26 \pm 0.050$ & nd & $0.20 \pm 0.055$ & $0.23 \pm 0.042$ & 18
\end{tabular}

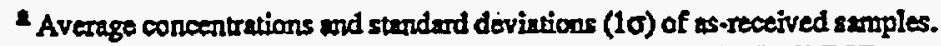

Average $\$ 2$ equals the average of samples $\$ 2-1$, $* 2-2$, and $\$ 2-3$. \% RSD equals the standard deviation divided by the average multiplied by 100 .

nd $=$ not determined 
WSRC-TR-94-057

- page 16 -

January 26, 1994

Anion Analyses of Water-Soluble Solids

The solutions obtained from the inhibited water dissolution of the saltcake sample were analyzed by ion chromatography and gravimetric methods to determine anion content. The results are shown in Table XIII. Nitrate and carbonate were the major anions in the saltcake sample. These results were consistent with the XRD analysis that identified sodium nitrate and sodium carbonate crystalline phases in the dried saltcake sample. The concentrations of the other anions were consistent with previous reports which have estimated the composition of high-level waste [8,9]. The higher carbonate concentration reflects the absorption of atmospheric carbon dioxide and reaction with hydroxide to form carbonate in the aged waste.

Table XII. Anion Analytical Results for Water-Soluble Solids Concentration (wt \%)

\begin{tabular}{|c|c|c|c|c|c|}
\hline Anion & $\# 1-1$ & $\# 2-1$ & \#2-3 & Ave耘2 & $\% \mathrm{RSD}$ \\
\hline Free OH- & $2.0 \pm 0.16$ & $1.0 \pm 0.0090$ & $1.5 \pm 0.0061$ & $: 1.3 \pm 0.35$ & 27 \\
\hline $\mathrm{Al}(\mathrm{OH})_{4}^{-}$ & $1.0 \pm 0.15$ & $0.22 \pm 0.012$ & $0.70 \pm 0.17$ & $0.46 \pm 0.34$ & 74 \\
\hline $\mathrm{CO}_{3}{ }^{2-}$ & $11.3 \pm 0.60$ & $6.5 \pm 0.79$ & $4.7 \pm 0.92$ & $5.6 \pm 1.3$ & 23 \\
\hline $\mathrm{NO}_{3}^{-}$ & $40.6 \pm 1.6$ & $44.1 \pm 1.5$ & $46.3 \pm 0.00034$ & $45.2 \pm 1.6$ & 3.4 \\
\hline $\mathrm{NO}_{2}^{-}$ & $0.98 \pm 0.048$ & $0.50 \pm 0.0089$ & $0.80 \pm 0.026$ & $0.65 \pm 0.21$ & 32 \\
\hline $\mathrm{PO}_{4}^{3-}$ & $0.71 \pm 0.20$ & $0.98( \pm 0.11$ & $0.54 \pm 0.043$ & $0.76 \pm 0.31$ & 41 \\
\hline $\mathrm{SO}_{4}{ }^{2-}$ & $1.2 \pm 0.20$ & $<0.038 \pm 0.0020$ & $0.65 \pm 0.14$ & $0.34 \pm 0.43$ & 130 \\
\hline $\mathrm{C}_{2} \mathrm{O}_{4}{ }^{2-}$ & $0.17 \pm 0.016$ & $<0.076( \pm 0.0040$ & $<0.077 \pm 0.0010$ & $<0.077 \pm 0.00071$ & 0.9 \\
\hline $\mathrm{Cl}^{-}$ & $0.024 \pm 0.0056$ & $0.020 \pm 0.00031$ & $0.020 \pm 0.0066$ & $0.020 \pm 0.00$ & 0 \\
\hline Total Anion & $58.0 \pm 3.0$ & $53.3 \pm 2.4$ & $55.2 \pm 1.3$ & $54.3 \pm 1.3$ & ' 2.4 \\
\hline
\end{tabular}

Average concentrations and standard deviations (10) of as-received samples. Average \#2 equals the average of samples \#2-1, \#2-2, and \#2-3. \% RSD equals the standand deviation divided by the everage mulaplied by 100 .

The analytical results for aluminate and phosphate determined by gravimetric and ion chromatographic (IC) methods were compared to the Al and P results obtained from the inductively-coupled plasma emission spectrometric (ICP-ES) method (see Table XIV). There was poor agreement between the different methods. In all cases, the IC and gravimetric results were higher than those determined by ICP-ES. Additional method development is recommended to determine the cause of the poor agreement. 
WSRC-TR-94-057

- page 17 -

January 26, 1994

Table XIV. Comparison of Analytical Results for Aluminum and Phosphorous

\begin{tabular}{|c|c|c|c|c|}
\hline \multirow[b]{2}{*}{ Analyte } & \multirow[b]{2}{*}{ Method } & \multicolumn{2}{|c|}{ Concentration (wt \%) } & \multirow[b]{2}{*}{$\# 2-3$} \\
\hline & & \#1. I & \#2-1 & \\
\hline $\mathrm{Al}(\mathrm{OH})_{4}^{-}$ & Gravimetric & $1.0 \pm 0.15$ & $0.22 \pm 0.01$ & $0.70 \pm 0.17$ \\
\hline Al & ICP-ES & $0.21^{b}$ & $0.093 \pm 0.005$ & $0.095 \pm 0.06$ \\
\hline $\mathrm{PO}_{4}^{3-}$ & IC & $0.71 \pm 0.20$ & $0.98 \pm 0.11$ & $0.54 \pm 0.043$ \\
\hline $\mathbf{P}$ & ICP-ES & $0.37^{b}$ & $0.34 \pm 0.002$ & $0.25 \pm 0.007$ \\
\hline
\end{tabular}

\footnotetext{
Average concentrations of as-received sumples. Numbers in parenticsis ane

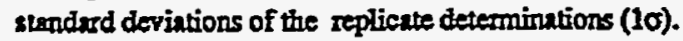

bSingle determination.
}

The total cation, total anion, and insoluble solids contents for each sample were summed to determine a total solids content for the as-received samples (see Table XV). The calculated total solids content was then compared to that determined by drying the as-received sample at $100^{\circ} \mathrm{C}$. Fairly good agreement between the two totals was obtained for each of the samples. This indicated that the overall elemental and chemical analyses of the samples were consistent and that no major component(s) had not been identified.

The total equivalents for cations and anions were calculated for each sample. Both should be the same to maintain an overall neutral charge. For sample \#1-1, excellent agreement in the cation and anion equivalents was observed. For samples \#2-1 and \#2-3, the agreement was not as good, and suggested that not all of the anionic species had been accounted for in the chemical analyses. The unaccounted anionic species may be carbonate. For samples \#2-1- and \#2-3, the carbonate content was about half of that found in sample \#1-1. All other anionic species were similar for each of the samples. 
WSRC-TR-94-057

- page 18 -

January 26, 1994

Table XV. Saltcake Solids Mass and Charge Balance

\section{Concentration (wt \%)}

$\# 1-1$

\#2-1

\#2-3

\begin{tabular}{llll}
\hline Total Cation & $28.0 \pm 0.6$ & $27.9 \pm 1.6$ & $27.3 \pm 0.4$ \\
Total Anion & $58.0 \pm 3.0$ & $53.3 \pm 2.4$ & $55.2 \pm 1.3$ \\
Insoluble Solids & $1.7 \pm 0.03$ & $0.89 \pm 0.11$ & $0.77 \pm 0.15$ \\
CalculatedTotal Solids Content ${ }^{b}$ & $87.7 \pm 3.2$ & $82.1 \pm 4.1$ & $83.3 \pm 1.9$ \\
Measured Total Solids Content & $86.3 \pm 1.3$ & $89.0 \pm 3.6$ & $89.2 \pm 2.4$
\end{tabular}

\section{Concentration (mole/100 g saltcake)}

$\begin{array}{lllll}\text { Total Cation Equivalentsc } & 1.22 & 1.21 & : & 1.19 \\ \text { Total Anion Equivalents } & & 1.23 & 1.03 & 1.05\end{array}$

\footnotetext{
Average concentrations and stardard deviutious (10) of replicate samples.

b Calculated total solids content equals the sum of the fotal cation, totul anion and insoluble solids.

OTotal cation equivalents detemined by summing the indivingal cation equivalents culculated by dividing each total cotion weight by its atomic weight and multiplying by its change.

dTotal anion eqivalents were desernined in a menner similar to that for the cation weights. Esch equivalent weight was mulliplied by the mionic charge.
}

Radiochemical Analyses

The as-received samples and the water soluble solids were analyzed for radiochemical content. The results are giver in Table XVI. Radionuclides detected included Cs-137, Cs-134, Sr-90, Tc-99, and Sn-126. Cesium-137 was the predominant radioactive material found in all of the samples.

The concentration of St-90 was fairly low, most of which was not soluble in inhibited water. Because of the low concentration, removal of Sr-90 would not be necessary to meet the recommended saltstone feed requirements[10]. The Tc-99 results for the total sample and soluble solids were not consistent for the March sample (\#1-1). More Tc-99 was found in the water-soluble solids than would be predicted based on that measured for the total sample. The Tc-99 content was not determined for the as-received saltcake for the July samples. However, based on the results for both the March and July samples, salt solutions prepared from the dissolution of the water-soluble solids would meet the Tc-99 limit for Z-Area salt solution feed specifications." 
WSRC-TR-94-057

- page 19 -

January 26, 1994

Table XVI. Radiochemical Analytical Results

\begin{tabular}{lllll} 
& \multicolumn{4}{c}{ Concentration of As-Received Saltcake Sample $(\mu \mathrm{Ci} / \mathrm{g})^{\mathrm{a}}$} \\
Badionuclide & $\#$ \#1-1 & \#2-1 & \#2-2 & \#2-3 \\
Cs-137 & $108 \pm 4$ & $65 \pm 14$ & $175 \pm 11$ & $40 \pm 2$ \\
Cs-134 & $0.11 \pm 0.01$ & $0.047^{b}$ & $0.16 \pm 0.02$ & $0.042 \pm 0.015$ \\
Sr-90 & $0.012 \pm 0.001$ & nd & nd & nd \\
Tc-99 & $0.013 \pm 0.001$ & nd & nd & nd \\
Ru-106 & $<0.057$ & nd & nd & nd \\
Eu-154 & $<0.22$ & nd & nd & nd \\
Eu-155 & $<0.22$, & nd & nd & nd \\
Sn-126 & $<0.18$ & nd & nd $:$ & nd
\end{tabular}

\section{Concentration of Water-Soluble Solids $(\mu \mathrm{Ci} / \mathrm{g})^{\mathrm{z}}$}

Radionuclide

$$
\text { \#1-1 }
$$

\#2-1

\#22

\#2-3

Cs-137

$$
106 \pm 3
$$

$63 \pm 0.3$

nd

$115 \pm 27$

Cs-134

$0.10^{\mathrm{b}}$

nd

$0.16^{\mathrm{b}}$

Sr-90

$0.0034 \pm 0.0002$

$<0.0015$

nd

$<0.011$

Tc-99

$0.038 \pm 0.002$

$0.024 \pm 0.005$

nd

$0.022 \pm 0.005$

Ru-106

$<0.0038$

$<0.0015$

nd

$<0.16$

Eu-154

$<0.024$

$<0.00061$

nd

$<0.016$

Eu-155

$<0.026$

nd

nd

nd

Sb-125

nd

$5 n-126$

$<0.026$

$<0.0023$

nd

$<0.078$

$0.0024 \pm 0.0001$ nd

$<0.023$

Average concentration of duplicute samples. Numbers in parenthesis are $1 \sigma$ standand deviation.

b Single result above detection limit reported nd $=$ not determined 
WSRC-TR-94-057

- page 20 -

January 26, 1994

\section{QUALITY ASSURANCE}

The handling and analysis of the samples were performed in accordance with the requirements specified in the Task and Quality Assurance Plan[2]. Based on the results obtained from the earlier March sample, the number of replicate dissolutions was decreased from five to two. Two synthetic saltcake materiais containing no added uranium and a known quantity of uranium were measured along with the unknown saltcake samples. Based on the results of the uranium saltcake standard material, it is concluded that the uranium results for the Tank $41 \mathrm{H}$ saltcake are valid by both the ICP/MS and TIMS methods. The three solutions used in the dissolutions were also analyzed to establish a baseline for the ICP-ES results. All laboratory data are recorded in laboratory notebooks, WSRC-NB-93-175 and WSRC-NB-93-339 maintained by D. T. Hobbs.

\section{REFERENCES}

1. D. T. Hobbs, C. J. Coleman, and R. N. Mahannah, "Final Report: Analysis of the Tank 41H Saltcake Sampie \#1," WSRC-TR-93-377, August 20, 1993.

2. D. T. Hobbs, "Task and Quality Assurance Plan for the Analysis of Tank 41 H Saltcake Samples (U)," WSRC-RP-93-495, rev, 0, March 28, 1993.

3. P. L. Gray, presentation at the POW Meeting, July 16, 1993.

4. Memorandum from J. A. Pike to B. L. Lewis, etal, "Tank Chemistry Report, November 1992 (U)", WER-HLE-921380, December 17, 1992.

5. G. A. Burney and R. M. Harbour, "Radiochemistry of Neptunium," National Academy of Sciences Report, NAS-NS-3060, Published by the Technical Information Center, Office of

- Information Services, United States Atomic Energy Commission, Issued December; 1974.

6. "Process Requirements for the In-Tank Precipitation Process," WSRC-IM-91-63, Rev.'́, September 21, 1992.

7. D. D. Walker and B. A. Hamm, "Material Balance and Planned Operating Schedule for the In-Tank Process(U)," WSRC-RP-89-1303, December 27, 1989.

8. J. R. Fowler, "Composition of F Area Soluble High-Level Waste," DPST-8\#2-390, March 10, 1982.

9. J. R. Fowler, "Composition of $\mathrm{H}$ Area and SRP Soluble High-Level Waste," DPST-82-502, April 28, 1982.

10. C. A. Langton and E. L. Wilhite, "Recommended Saltstone Feed Specifications for Z-Area," DPST-88-372, March 15, 1988. 
WSRC-TR-94-057

- page 21 -

January 26, 1994

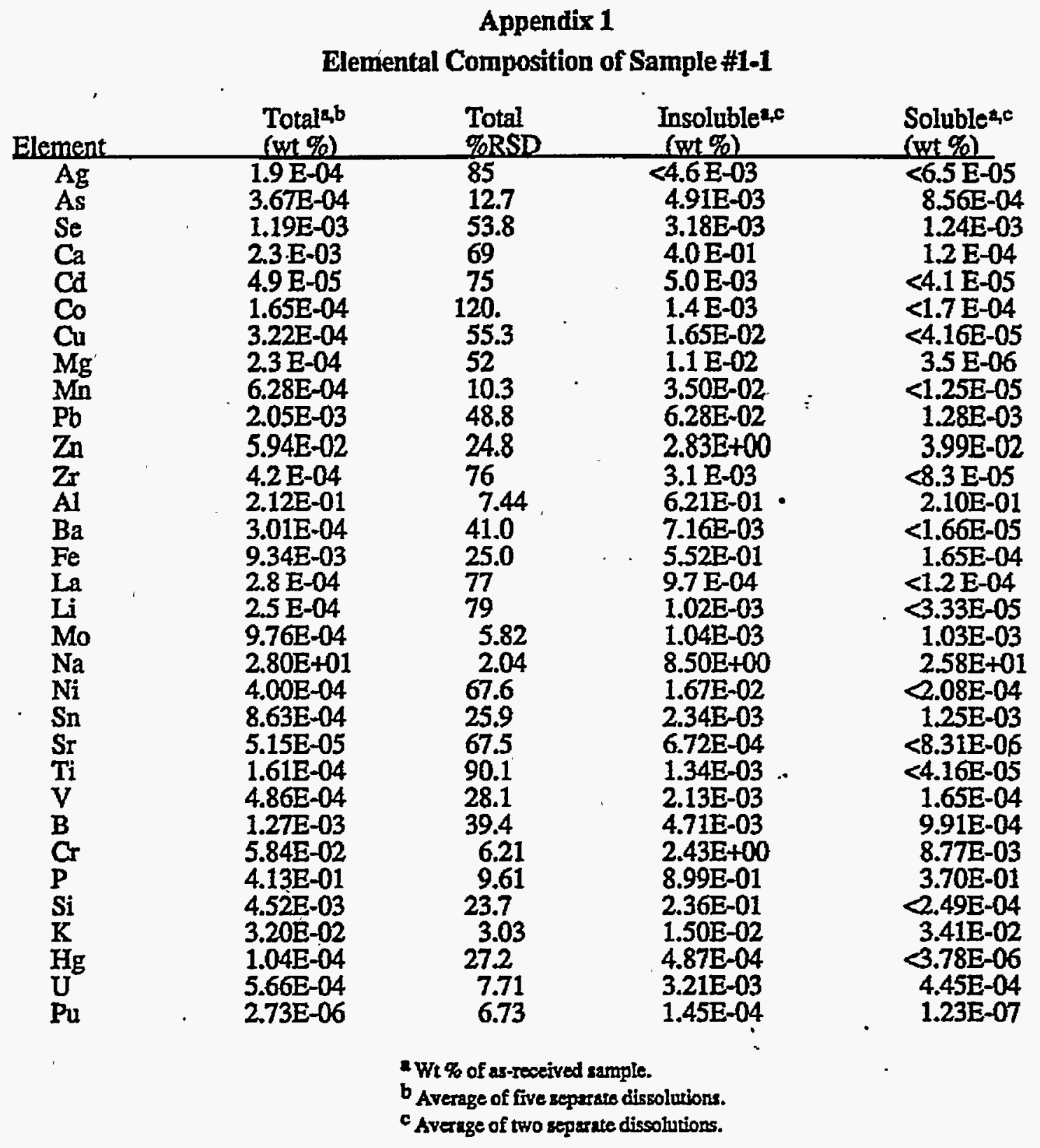


WSRC-TR-94-057

- page 22 -

January 26, 1994

\section{Appendix 2}

Elemental Composition of Sample \#2-1

Total Sample[1]

Water Soluble Fraction[1]

Water Insoluble Fraction[2]

\begin{tabular}{|c|c|c|c|c|c|c|}
\hline Element & $\begin{array}{l}\text { Average } \\
\text { Wt.\% }\end{array}$ & $\begin{array}{l}\text { Std. Dev.[3] } \\
\text { Wt.\% }\end{array}$ & $\begin{array}{l}\text { Average } \\
\text { Wt.\% }\end{array}$ & $\begin{array}{l}\text { Std. Dev.[3] } \\
\text { Wt.5 }\end{array}$ & $\begin{array}{l}\text { Average } \\
\text { WL. } 5\end{array}$ & $\begin{array}{c}\text { Std. Dev.[3] } \\
\text { Wt. } \%\end{array}$ \\
\hline Ag & $<1.75 E-04$ & $<6.35 E-07$ & $<1.68 \mathrm{E}-04$ & $<1.93 \mathrm{E}-05$ & $<7.23 \mathrm{E}-04$ & \\
\hline As & $<1.75 \mathrm{E}-03$ & $<6.35 \mathrm{E}-06$ & $<1.68 \mathrm{E}-03$ & $<1.93 \mathrm{E}-04$ & $.8 .49 \mathrm{E}-03$ & \\
\hline Se & $\mathrm{mr}$ & & 2.77E-04 & 5.54E-04 & $1.15 \mathrm{E}-02$ & \\
\hline $\mathrm{Ca}$ & $3.02 E-03$ & $1.21 \mathrm{E}-03$ & $8.49 \mathrm{E}-04$ & $5.25 \mathrm{E}-04$ & $2.81 E+\infty 0$ & $4.95 \mathrm{E}-02$ \\
\hline $\mathrm{Cd}$ & $2.65 E-05$ & $8.54 E-06$ & $<8.40 \mathrm{E}-05$ & $<9.66 \mathrm{E}-06$ & $<3.61 \mathrm{E}-04$ & \\
\hline Co & 8.55E-05 & 3.89E-05 & $<3.36 \mathrm{E}-04$ & $<3.86 E_{-05}$ & $<1.45 \mathrm{E}-03$ & \\
\hline $\mathrm{Cu}$ & $1.28 \mathrm{E}-04$ & $4.09 \mathrm{E}-05$ & $<8.40 \mathrm{E}-05$ & $<9.66 \mathrm{E}-06$ & $3.54 \mathrm{E}-03$ & 5.11E-04 \\
\hline $\mathrm{Mg}_{\mathrm{B}}$ & $1.74 \mathrm{E}-04$ & 1.15E-04 & 2.23E-05 & $1.38 \mathrm{E}-05$ & $3.86 \mathrm{E}-02$ & $4.60 \mathrm{E}-04$ \\
\hline Mn & 2.43E-04 & $1.26 \mathrm{E}-04$ & $<2.52 \mathrm{E}-05$ & $<2.90 \mathrm{E}-06$ & 3.35E-02 & $3.32 E-04$ \\
\hline Po & $6.39 \mathrm{E}-04$ & $1.01 E-06$ & $<1.68 \mathrm{E}-03$ & $<1.93 \mathrm{E}-04$ & 9.3.9E-03 & \\
\hline $\mathrm{Zn}$ & $1.42 \mathrm{E}-02$ & 2.32E-03 & $2.08 \mathrm{E}-03$ & $1.12 \mathrm{E}-03$ & $1.16 E+\infty 0$ & $1.07 \mathrm{E}-02$ \\
\hline $\mathrm{Zr}$ & $8.92 E-05$ & $1.96 E-05$ & $<1.68 \mathrm{E}-04$ & $<1.93 \mathrm{E}-05$ & $6.63 \mathrm{E}-03$ & 9.45E-04 \\
\hline Al & $1.07 \mathrm{E}-01$ & $2.02 E-02$ & 9.2TE-02 & $5.02 \mathrm{E}-03$ & $6.55 \mathrm{E}-01$ & $1.45 \mathrm{E}-02$ \\
\hline $\mathrm{Ba}$ & $1.00 \mathrm{E}-04$ & $2.27 E-0.5$ & $<3.36 \mathrm{E}-05$ & $<3.86 \mathrm{E}-06$ & $4.12 E-03$ & $3.58 \mathrm{E}-04$ \\
\hline $\mathrm{Fe}$ & $3.12 E-02$ & $2.59 \mathrm{E}-02$ & $4.48 \mathrm{E}-04$ & & $2.33 E+\infty 0$ & 2.01E-02 \\
\hline $\mathbf{L a}$ & . 2.62E-04 & $6.12 \mathrm{E}-05$ & $<2.52 \mathrm{E}-04$ & $<2.90 \mathrm{E}-05$ & 8.35E-03 & \\
\hline $\mathrm{Li}$ & $3.93 E-05$ & $1.58 \mathrm{E}-05$ & $<6.72 E-05$ & $<7.73 \mathrm{E}-06$ &.$<2.89 \mathrm{E}-04$ & 1 \\
\hline Mo & 5.39E-04 & $1.14 \mathrm{E}-04$ & $<3.36 \mathrm{E}-04$ & $<3.86 \mathrm{E}-05$ & $1.99 \mathrm{E}-03$ & \\
\hline $\mathrm{Na}$ & ' 2.79E+01 & $1.56 \mathrm{E}+00$ & $2.70 \mathrm{E}+01$ & $1.23 \mathrm{E}+00$ & $2.32 \mathrm{E}+01$ & $1.20 \mathrm{E}-01$ \\
\hline $\mathrm{Ni}$ & $1.95 \mathrm{E}-04$ & 5.19E-05 & $<4.20 \mathrm{E}-04$ & $<4.83 \mathrm{E}-05$ & 7.95E-03 & $1.94 \mathrm{E}-03$ \\
\hline $\mathrm{Sn}$ & $1.30 \mathrm{E}-03$ & $6.64 \mathrm{E}-04$ & $1.22 \mathrm{E}-03$ & $3.62 \mathrm{E}-04$ & $1.01 \mathrm{E}-02$ & $1.30 \mathrm{E}-03$ \\
\hline Sr & $1.62 \mathrm{E}-05$ & $6.09 \mathrm{E}-06$ & $<1.68 \mathrm{E}-05$ & $<1.93 \mathrm{E}-06$ & $159 E-03$ & $153 \mathrm{E}-04$ \\
\hline $\mathrm{Ti}$ & 4.53E-05 & $1.83 \mathrm{E}-05$ & $<8.40 \mathrm{E}-05$ & $<9.66 \mathrm{E}-06$ & $1.19 \mathrm{E}-03$ & \\
\hline V & 4.22E-04 & $1.75 \mathrm{E}-04$ & $<8.40 \mathrm{E}-05$ & $<9.66 \mathrm{E}-06$ & $1.45 E-03$ & $7.66 \mathrm{E}-04$ \\
\hline B & 4.37E-04 & $1.00 \mathrm{E}-04$ & 5.67E-04 & & $3.57 \mathrm{TE}-02$ & $6.46 \mathrm{E}-03$ \\
\hline$C$ & $9.19 \mathrm{E}-02$ & 2.13E-02 & 2.13E-02 & $3.22 \mathrm{E}-03$ & $5.72 \varepsilon+00$ & $5.13 E-02$ \\
\hline $\mathbf{P}$ & 3.74E-01 & 8.97E-02 & $3.39 E-01$ & 2.37E-02 & $9.24 E-01$ & 2.79E-02 \\
\hline $\mathbf{S i}$ & $1.2 \mathrm{LE}-03$ & 4.81E-04 & $<$ 5.65E-04 & & $2.59 \mathrm{E}-01$ & 5.96E-02 \\
\hline $\mathbf{K}$ & $1.91 \mathrm{E}-02$ & 2.41E-03 & $1.37 \mathrm{E}-02$ & $4.29 \mathrm{E}-03$ & nd & \\
\hline $\mathrm{Hg}$ & $2.91 \mathrm{E}-05$ & 3.71E-06 & $<7.60 \mathrm{E}-06$ & $<3.97 \mathrm{E}-07$ & nd & \\
\hline $\mathbf{U}$ & $6.0 \mathrm{E}-04$ & $6.3 \mathrm{E}-05$ & 3.7E-04 & $6.0 \mathrm{E}-06$ & $6.2 E-02$ & $2.00 \mathrm{E}-02$ \\
\hline $\mathrm{Pu}$ & $-2.7 E-06$ & $8.5 \mathrm{E}-08$ & $\mathrm{nr}$ & & 1.5E-03 & $1.40 \mathrm{E}-04$ \\
\hline
\end{tabular}

[1] Average of four different nemple dissolutions

(2) Average of duplicale mearurements of single discolvitioc.

[3] Blent valve for munderd devixtion indicaves ringle reculs

or a noce toported

$n d=\cos d e x+m$ mined 
WSRC-TR-94-057

- page 23 .

January 26, 1994

\section{Appendix 3}

Elemental Composition of Sample \#2-2

Total Sample[I]

\begin{tabular}{|c|c|c|c|}
\hline Element & $\begin{array}{l}\text { Average } \\
\text { Wt.\% }\end{array}$ & $\begin{array}{l}\text { Std. Der.[2] } \\
\text { Wt:\% }\end{array}$ & \\
\hline $\mathrm{Ag}$ & $<4.01 \mathrm{E}-04$ & $<7.70$ E-05 & \\
\hline As & $<4.01 \mathrm{E}-03$ & $<7.70 \mathrm{E}-04$ & \\
\hline Se & $\pi$ & & \\
\hline $\mathrm{Ca}$ & $8.23 E-03$ & $6.93 \mathrm{E}-03$ & \\
\hline $\mathrm{Cd}$ & 4.47E-05 & $9.66 \mathrm{E}-06$ & \\
\hline $\mathrm{Co}$ & $6.40 \mathrm{E}-05$ & $1.57 \mathrm{E}-05$ & \\
\hline $\mathrm{Cu}$ & $1.70 \mathrm{E}-04$ & 2.57E-05 & \\
\hline $\mathrm{Mg}$ & $1.10 \mathrm{E}-03$ & $1.16 \mathrm{E}-03$ & , \\
\hline Mn & 2.07E-04 & $8.92 E-05$ & \\
\hline $\mathrm{Pb}$ & $1.29 E-03$ & 1.91E-04 & \\
\hline $\mathrm{Zn}$ & $2.14 E-01$ & $6.39 \mathrm{E}-02$ & \\
\hline $\mathbf{Z r}$ & $1.25 \mathrm{E}-04$ & $1.72 \mathrm{E}-06$ & \\
\hline Al. & $2.47 \mathrm{E}-01$ & $5.78 \mathrm{E}-02$ & \\
\hline $\mathrm{Ba}$ & $1.39 \mathrm{E}-04$ & $9.27 \mathrm{E}-05$ & \\
\hline $\mathrm{Fe}$ & $2.40 \mathrm{E}-02$ & $1.60 \mathrm{E}-02$ & \\
\hline $\mathbf{L a}$ & $222 E-04$ & $7.96 E-06$ & \\
\hline $\mathrm{Li}$ & $2.50 \mathrm{E}-05$ & 1.04E-05 & \\
\hline Mo & 1.04E-03 & 5.08E-05 & \\
\hline $\mathbf{N a}$ & $2.665+01$ & $7.98 \mathrm{E}-01$ & \\
\hline $\mathbf{N i}$ & $1.03 E-04$ & $1.12 E-05$ & \\
\hline $\mathrm{Sn}$ & $1.26 \varepsilon-03$ & 8.77E-05 & - \\
\hline $\mathbf{S r}$ & $1.40 \mathrm{E}-05$ & $1.16 E-06$ & \\
\hline$T i$ & $3.55 \mathrm{E}-05$ & $1.03 \mathrm{E}-05$ & \\
\hline $\mathbf{v}$ & $3.95 \mathrm{E}-04$ & 4.03E-05 & \\
\hline $\mathbf{B}$ & 7.62E-04 & $3.94 E-05$ & - \\
\hline$a$ & $7.88 \mathrm{E}-02$ & $2.19 \mathrm{E}-02$ & \\
\hline $\mathbf{P}$ & $4.32 E-01$ & $1.62 E-01$ & \\
\hline $\mathbf{S i}$ & $2.15 \mathrm{E}-02$ & $234 \mathrm{E}-02$ & \\
\hline $\mathbf{K}$ & $3.07 \mathrm{E}-02$ & $7.44 \mathrm{E}-04$ & \\
\hline $\mathrm{Hg}$ & $5.47 E-05$ & $1.22 E-05$ & \\
\hline $\mathbf{U}$ & $4.8 E-04$ & $2.5 \mathrm{E}-05$ & \\
\hline $\mathbf{P u}$ & $4.2 E-06$ & 9.7E-07 & \\
\hline \multicolumn{4}{|c|}{ 1) Averige of four diftereat remple dissolutions. } \\
\hline
\end{tabular}


WSRC-TR-94-057

- page 24 -

January 26, 1994

Appendix 4

Elemental Composition of Sample \#2-3

Total Sample[1]

Water Soluble Fraction[1]

Water Insoluble Fraction[2]

\begin{tabular}{|c|c|c|c|c|c|c|}
\hline Element & $\begin{array}{l}\text { Average } \\
\text { WL.\% }\end{array}$ & $\begin{array}{l}\text { Std. Dev.[3] } \\
\text { WL. } \%\end{array}$ & $\begin{array}{l}\text { Average } \\
\text { Wt.\%. }\end{array}$ & $\begin{array}{l}\text { Std. Dev_\{3] } \\
\text { Wt.\% }\end{array}$ & $\begin{array}{l}\text { Average } \\
\text { Wt. \% }\end{array}$ & $\begin{array}{c}\text { Std. Dev.[3] } \\
\text { WL. \% }\end{array}$ \\
\hline$\overline{A g}$ & $<1.71 \mathrm{E}-04$ & $<5.07 \mathrm{E}-07$ & $1.69 \mathrm{E}-04$ & $1.76 \mathrm{E}-05$ & $<6.04 \mathrm{E}-04$ & \\
\hline As & $<1.71 \mathrm{E}-03$ & $<5.07 \mathrm{E}-06$ & $1.69 \mathrm{E}-03$ & $1.76 \mathrm{E}-04$ & 8.24E-03 & \\
\hline Se & $\mathrm{nr}$ & & $3.29 \mathrm{E}-05$ & $6.04 E-05$ & $8.00 \mathrm{E}-03$ & \\
\hline $\mathrm{Ca}$ & $3.29 \mathrm{E}-03$ & $1.62 \mathrm{E}-03$ & 8.65E-04 & 7.11E-04 & $2.17 E+100$ & 3.63E-02 \\
\hline $\mathrm{Cd}$ & 5.12E-05 & $1.22 \mathrm{E}-05$ & 8.43E-05 & 8.81E-06 & 3.37E-03 & $5.76 \mathrm{E}-04$ \\
\hline Co & $6.80 \mathrm{E}-05$ & $3.36 \mathrm{E}-05$ & 3.37E-04 & $3.53 \mathrm{E}-05$ & $<1.21 \mathrm{E}-03$ & \\
\hline $\mathrm{Cu}$ & $1.68 \mathrm{E}-04$ & $5.97 \mathrm{E}-05$ & $8.43 E-05$ & 8.81E-06 & $1.24 \mathrm{E}-02$ & $1.02 E-03$ \\
\hline $\mathrm{Mg}$ & $2.64 \mathrm{E}-0.4$ & $1.66 \mathrm{E}-04$ & $2.10 \mathrm{E}-05$ & $7.26 \mathrm{E}-\infty 6$ & $3.31 E-02$ & 2.35E-04 \\
\hline $\mathrm{Mn}$ & $2.07 \mathrm{E}-04$ & 1.38E-04 & 2.53E-05 & $2.64 \mathrm{E}-06$ & - $3.82 \mathrm{E}-02$ & $7.26 \mathrm{E}-04$ \\
\hline Po. & $1.03 E-03$ & 2.07E-04 & $1.69 \mathrm{E}-03$ & 1.76E-04 & $2.42 E-02$ & $5.76 \mathrm{E}-03$ \\
\hline $\mathbf{Z n}$ & $6.87 \mathrm{E}-02$ & $3.12 \mathrm{E}-02$ & $2.64 \mathrm{E}-02$ & $3.01 \mathrm{E}-02$ & $3.17 \mathrm{E}+00$ & $5.42 \mathrm{E}-02$ \\
\hline $\mathbf{Z r}$ & $1.12 E-04$ & $6.68 E-05$ & 1.69E-04 & 1.76E-05 & $3.76 E-03$ & 1.13E-03 \\
\hline Al & $1.01 E-01$ & $4.79 \mathrm{E}-02$ & $9.46 \mathrm{E}-02$ & $5.68 \mathrm{E}-02$ & $4.84 \mathrm{E}-01$ & 1.63E-02 \\
\hline $\mathrm{Ba}$ & 9.05E-05 & 4.35E-05 & 3.37E-05 & $3.53 \mathrm{E}-06$ & $1.02 E-02$ & $6.40 E-04$ \\
\hline $\mathrm{Fe}$ & $3.58 \mathrm{E}-02$ & 2.17E-02 & $1.69 \mathrm{E}-04$ & $1.76 \mathrm{E}-05$ & $6.97 \mathrm{E}+00$ & 121E-01 \\
\hline $\mathrm{La}$ & $2.57 \mathrm{E}-04$ & 5.61E 05 & 253E-04 & $2.64 \mathrm{E}-05$ & 7.12E-03 & \\
\hline $\mathbf{L i}$ & 3.17E-05 & $1.82 \mathrm{E}-05$ & $6.74 E-05$ & 7.05E-06 & $\leqslant 2.41 E-04$ & \\
\hline Mo & 7.55E-04 & $1.39 \mathrm{E}-04$ & $5.48 \mathrm{E}-04$ & $2.07 E-05$ & $2.54 E-03$ & \\
\hline $\mathrm{Na}$ & $2.73 E+01$ & $3.78 \mathrm{E}-01$ & $2.7 \mathrm{IE}+01$ & $1.20 E+00$ & $2.39 E+01$ & 2.53E-01 \\
\hline $\mathrm{Ni}$ & $1.18 \mathrm{E}-04$ & $3.64 \mathrm{E}-05$ & 4.21E-04 & 4.41E.05 & $5.06 E-03$ & 1.17E-03 \\
\hline $\mathrm{Sn}$ & $1.06 \mathrm{E}-03$ & $4.08 \mathrm{E}-04$ & $6.78 E-04$ & & $1.56 \mathrm{E}-02$ & $1.28 \mathrm{E}-03$ \\
\hline Sr & $1.75 \mathrm{E}-05$ & $7.39 \mathrm{E}-06$ & 1.69E-05 & $1.76 \mathrm{E}-06$ & 1.55E-03 & $1.49 \mathrm{E}-04$ \\
\hline $\mathrm{Ti}$ & 4.38E-05 & 1.79E-05 & $8.43 E-05$ & 8.81E-06 & 1.0TE-03 & $7.90 \mathrm{E}-04$ \\
\hline $\mathbf{v}$ & 5.04E-04 & $1.50 E-04$ & 8.43E-05 & 8.81E-06 & 8.72E-03 & $1.20 \mathrm{E}-03$ \\
\hline B & 5.57E-04 & $9.26 \mathrm{E}-05$ & 3.37E-04 & $3.53 E-05$ & $<8.72 \mathrm{E}-03$ & \\
\hline$C$ & $5.78 \mathrm{E}-02$ & $1.36 \mathrm{E}-02$ & $6.79 \mathrm{E}-03$ & $1.00 \mathrm{E}-03$ & $3.93 \mathrm{E}+00$ & 8.11E-02 \\
\hline $\mathbf{P}$ & $3.26 \mathrm{E}-0 \mathrm{I}$ & $5.95 E-02$ & 2.51E-01 & $7.28 E-02$ & $7.05 E+00$ & $1.24 \mathrm{E}-01$ \\
\hline Si & $2.38 \mathrm{E}-03$ & 8.44E-04 & $5.06 \mathrm{E}-04$ & $5.29 \mathrm{E}-05$ & $2.01 E-01$ & $5.51 E^{\prime}-02$ \\
\hline $\mathbf{K}$ & 2.37E-02 & $2.76 \mathrm{E}-03$ & $1.98 \mathrm{E}-02$ & 1.13E-03 & nd & \\
\hline $\mathrm{Hg}$ & 5.93E-05 & 1.17E-05 & $<7.68 \mathrm{E}-06$ & $<1.01 \mathrm{E}-07$ & nd & \\
\hline $\mathbf{U}$ & 2.7E-04 & 1.5E-05 & $1.4 \mathrm{E}-04$ & $3.2 \mathrm{E}-05$ & $9.8 \mathrm{E}-03$ & $1.4 \mathrm{E}-04$ \\
\hline Pu & $2.9 \mathrm{E}-06$ & 2.7E-07 & $\mathfrak{m}$ & & 3.8E-04 & $4.2 \mathrm{E}-05$ \\
\hline \multicolumn{7}{|c|}{ [1] Average of four differear sumple dissolutioas. } \\
\hline \multicolumn{7}{|c|}{ [2] Avarige of duplicess meesurements of single dissolocion. } \\
\hline \multicolumn{7}{|c|}{ 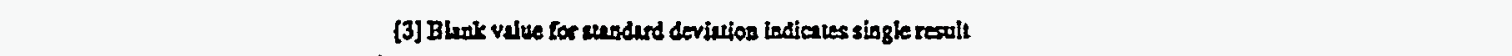 } \\
\hline \multicolumn{7}{|c|}{ ar = noose mored } \\
\hline \multicolumn{7}{|c|}{$n d x$ sot determined } \\
\hline & ، & & & & & \\
\hline & & & & & $\therefore$ & \\
\hline
\end{tabular}


WSRC-TR-94-057

- page 25

January 26, 1994

cc: G. T. Wright, 773-A

T. M. Monahon, 703-H

R. A. Scaggs, 703-H

J. Morin, 719-4A

R. G. Croley, 241-120H

J. N. Brooke, 241-120H

W. E. VanPelt, 241-152H

D. C. Wood, 705-21C

P. Rutland, 241-152H

J. E. Marra, 703-H

P.L. Gray, 703-H

M. C. Chandler, 703-H

J. S. Clemmons, 703-H

P. D. d'Entremont, 703-H

W. R. Jacobsen, 703-10C

P. C. Padezanin, 772-3F

J. E. Stewart, 772-3F

C. M. Gregory, 772-3F

S. L. Maxwell, 772-F

C. Y. Boler-Melton, 772-F

M. K. Holland, 772-3F

J. Satkowski, 772-3F

L. M. Papouchado, 773-A

C. R. Wolfe, 773-A

W. L. Tamosaitis, 773-A

A. L. Blancett, 773-A

W. S. Cavin, 773-A

P. F. Cloessner, 773-A

D. D. Walker, 773-A

M. J. Barnes, 773-A

N. E. Bibler, 773-A

M. C. Thompson, 773-A

D. G. Karraker, 773-A

A. Q. Goslen, 773-22A

TIM, 703-43A

IWT-LWP File, 773-A 